\title{
Borrelia burgdorferi sensu lato genospecies in Ixodes ricinus ticks feeding on passerine birds in southern Norway
}

\section{Jana Radzijevskaja ${ }^{1}$,}

Olav Rosef ${ }^{2}$,

Vesta Matulaityte $\dot{e}^{1}$,

\section{Algimantas Paulauskas ${ }^{1 \star}$ \\ ${ }^{1}$ Vytautas Magnus University, \\ Department of Biology, ileikos St. 8, \\ LT-44404 Kaunas, Lithuania}

${ }^{2}$ Rosef Field Research Station,

Frolandsveien 2667,

828 Mjåvatn, Norway

\begin{abstract}
Birds are increasingly considered important in the global dispersal of tick-borne pathogens. The purpose of this study was to investigate the prevalence of Borrelia burgdorferi sensu lato genospecies in Ixodes ricinus ticks collected on passerine birds from two ornithological stations (Jomfruland and Lista) in southern Norway. In both sampling sites a total of 608 (109 larvae and 499 nymphs) of immature ticks were collected from 157 infested birds representing 26 species. The presence of B. burgdorferi s.l. DNA in ticks was tested using direct PCR amplification of the ospA gene, localized on lp-54 plasmid in B. burgdorferi s.l. genome. Twenty one out of 157 infested (13\%) birds carried B. burgdorferi s.l. infected Ixodes ricinus ticks. B. burgdorferi s.l. DNA was detected in $19.7 \%$ of the tick samples. In total, $6.4 \%$ of larvae (7/109) and $10 \%$ of nymphs (50/499) were positive. The vast majority of infected ticks were found on blackbird (Turdus merula). The most frequent genospecies was B. garinii (85.5\%), followed by B. afzelii (9.0\%) and B. valaisiana (5.5\%). Five different B. garinii genotypes were identified. Our findings showed that the blackbirds may support the circulation and spread of B. garinii and B. valaisiana. B. garinii was not detected in questing ticks from investigated locations. B. afzelii genospecies, however, dominated in questing ticks, rodents and ticks from rodents.
\end{abstract}

Key words: passerine birds, Ixodes ricinus ticks, Borrelia burgdorferi s.l. genospecies

\section{INTRODUCTION}

Lyme borreliosis (LB) is the most frequent tickborne disease in the northern hemisphere, including Norway. In Europe, nine Borrelia genospecies belonging to the complex $B$. burgdorferi s.l. (B. burgdorferi sensu stricto, B. garinii, B. ba-

\footnotetext{
*Corresponding author. E-mail: a.paulauskas@gmf.vdu.lt
}

variensis, $B$. afzelii, B. valaisiana, B. lusitaniae, B. bissettii, B. spielmanii, and B. turdi) have been detected in the tick vector Ixodes ricinus (Stanek, Reiter, 2011; Hasle et al., 2011). According to the concept of host-specific Borrelia association, based on differential properties of the hosts complement systems, various reservoir hosts harbor different Borrelia species (Kurtenbach et al., 1998; Kurtenbach et al., 2002a). B. valaisiana and most 
OspA types of the highly heterogeneous B. garinii species are associated with birds (Kurtenbach et al., 2002b; Hanincová et al., 2003). It is epidemiologically important that the different genomic groups of B. burgdorferi s.l. cause diverse clinical manifestations of LB in humans: $B$. garinii is associated with neuroborreliosis (e. g. meningoradiculoneuritis) while B. afzelii is usually predominant in the skin forms (acrodermatitis chronica atrophicans), and B. burgdorferi s.s. is the common agent of arthritis (Ruzic-Sabljic et al., 2008).

Birds are considered important in the global dispersal of tick-borne pathogens and establishing foci of tick-borne diseases (Olsen et al., 1995; Comstedt et al., 2006). The migratory routes of birds in Europe are diverse with both North-South and West-East directions. It is, however, difficult to determine the place of origin of ticks that parasitize on migratory birds. Ixodid ticks can travel hundreds of kilometers on birds along migration routes before they get de-attached. The ticks that are transported to Norway with migratory birds could be transferred from a quite large area, because different species of birds have different overwintering areas, different migratory routes, and migrate in different periods during spring and autumn (Main, 2002). The dominant direction of migration during spring in Northern Europe is from southwest towards northeast, and the opposite direction during autumn (Acheson, 1975).

Previous studies conducted in Europe have shown that different bird species differ in their competence in transmitting of Borrelia pathogens and infect ticks. In Europe, pheasants (Phasianus colchicus), some passerine bird species, like blackbirds (Turdus merula) and song thrushes (Turdus philomelos), and a few seabird species have been shown to be reservoir competent for B. garinii and B. valaisiana (Kipp et al., 2006; Kurtenbach et al., 1998; Taragel'ová et al., 2008). Because the proportion of particular clinical forms of Lyme borreliosis varies in European countries, it has been of interest to analyze the distribution of different genospecies of B. burgdorferi s.l. in ticks and reservoir hosts.
The aim of our study was to investigate the occurrence of B. burgdorferi s.l. genospecies in ticks from passerine birds in Norway and compare Borrelia infection in ticks from vegetation and small rodents.

\section{MATERIALS AND METHODS}

\section{Sample collection}

Passerine birds were captured at two ornithological stations in the southern coast of Norway Jomfruland $\left(58^{\circ} 52^{\prime} \mathrm{N}, 09^{\circ} 36^{\prime} \mathrm{E}\right)$ and Lista $\left(58^{\circ} 07^{\prime} \mathrm{N}, 06^{\circ} 40^{\prime} \mathrm{E}\right)$ during the spring migratory period (April) in 2006-2007 (Table 1). The birds were identified, examined for ticks and released back into the wild. Only tick-infested birds were included in this study. Ticks were collected from birds using tweezers and placed in microtubes with $70 \%$ ethanol and placed at $4{ }^{\circ} \mathrm{C}$ before DNA analysis. All ticks were identified to species level using appropriate taxonomic keys (Filippova, 1977; Hillyard, 1996) and molecular assays.

\section{DNA extraction}

DNA extraction was performed after the ticks were removed from the birds and carried out by lysis in ammonium hydroxide (Rijpkema et al., 1996). Forty $\mu$ l for larvae and $80 \mu \mathrm{l}$ for nymph of $2.5 \%$ ammonia solution was added to the sample in a $0.5 \mathrm{ml}$ microcentrifuge tube and heated at $99^{\circ} \mathrm{C}$ for $25 \mathrm{~min}$ in a thermostat. After a brief centrifugation the tubes were opened and heated 10-15 $\mathrm{min}$ to evaporate ammonia. The lysates were stored at $-20^{\circ} \mathrm{C}$.

DNA from engorged ticks was extracted using the Genomic DNA Purification Kit (Thermo Fisher Scientific, Lithuania) according to the protocol suggested by the manufacturer.

\section{Molecular identification of tick species}

For accurate taxonomical identification of Ixodes ticks with damaged parts of gnathosoma we used species-specific PCR with Ixri-F/Ixri-R primers, as described previously (Paulauskas et al., 2009). 
Table 1. B. burgdorferi s.l. genospecies in Ixodes ricinus ticks feeding on passerine birds in Jomfruland and Lista

\begin{tabular}{|c|c|c|c|c|c|c|c|c|c|c|c|c|c|c|}
\hline \multirow{3}{*}{ Bird species } & \multirow{2}{*}{\multicolumn{2}{|c|}{$\begin{array}{l}\text { No of tested } \\
\text { ticks }\end{array}$}} & \multirow{2}{*}{\multicolumn{2}{|c|}{$\begin{array}{l}\text { n (\%) of } B b s l \\
\text { infected ticks }\end{array}$}} & \multicolumn{10}{|c|}{ B. burgdorferi s.l. genospecies, n (\%) of Bbsl infected ticks } \\
\hline & & & & & \multicolumn{2}{|c|}{$B g$} & \multicolumn{2}{|r|}{$B a$} & \multicolumn{2}{|c|}{$B s s / B g$} & \multicolumn{2}{|c|}{$B a / B g$} & \multicolumn{2}{|r|}{$B v$} \\
\hline & $\mathbf{L}$ & $\mathbf{N}$ & $\mathbf{L}$ & $\mathbf{N}$ & $\mathbf{L}$ & $\mathbf{N}$ & $\mathbf{L}$ & $\mathbf{N}$ & $\mathbf{L}$ & $\mathbf{N}$ & $\mathbf{L}$ & $\mathbf{N}$ & $\mathrm{L}$ & $\mathbf{N}$ \\
\hline \multicolumn{15}{|l|}{$\begin{array}{c}\text { Jomfruland } \\
(2006)\end{array}$} \\
\hline $\begin{array}{c}\text { Carduelis } \\
\text { cabaret }\end{array}$ & & 4 & & & & & & & & & & & & \\
\hline $\begin{array}{l}\text { Carduelis } \\
\text { cannabina }\end{array}$ & & 2 & & 1 & & 1 & & & & & & & & \\
\hline $\begin{array}{c}\text { Carduelis } \\
\text { chloris }\end{array}$ & & 4 & & & & & & & & & & & & \\
\hline $\begin{array}{l}\text { Turdus } \\
\text { merula }\end{array}$ & 39 & 223 & $7(18)$ & $32(14.4)$ & $7(18)$ & $27(12.1)$ & & $3(1.3)$ & & $1(0.5)$ & & $1(0.5)$ & & \\
\hline $\begin{array}{l}\text { Turdus philo- } \\
\quad \text { melos }\end{array}$ & & 3 & & & & & & & & & & & & \\
\hline $\begin{array}{c}\text { Erithacus } \\
\text { rubecula }\end{array}$ & 3 & 11 & & & & & & & & & & & & \\
\hline $\begin{array}{l}\text { Sylvia atrica- } \\
\text { pilla }\end{array}$ & 1 & & & & & & & & & & & & & \\
\hline Sylvia borin & & 4 & & & & & & & & & & & & \\
\hline $\begin{array}{l}\text { Sylvia com- } \\
\text { munis }\end{array}$ & 1 & & & & & & & & & & & & & \\
\hline $\begin{array}{l}\text { Sylvia cur- } \\
\text { ruca }\end{array}$ & & 2 & & & & & & & & & & & & \\
\hline $\begin{array}{l}\text { Hippolais } \\
\text { icterina }\end{array}$ & 8 & 2 & & & & & & & & & & & & \\
\hline $\begin{array}{c}\text { Fringilla } \\
\text { coelebs }\end{array}$ & 6 & 15 & & $1(6.7)$ & & $1(6.7)$ & & & & & & & & \\
\hline $\begin{array}{l}\text { Carpodacus } \\
\text { erythrinus }\end{array}$ & & 1 & & 1 & & & & 1 & & & & & & \\
\hline $\begin{array}{l}\text { Sturnus } \\
\text { vulgaris }\end{array}$ & & 6 & & & & & & & & & & & & \\
\hline $\begin{array}{l}\text { Phylloscopus } \\
\text { collybita }\end{array}$ & 2 & & & & & & & & & & & & & \\
\hline $\begin{array}{l}\text { Phoenicurus } \\
\text { phoenicurus }\end{array}$ & & 3 & & & & & & & & & & & & \\
\hline Total & 60 & 280 & $7(11.7)$ & $35(12.5)$ & $7(11.7)$ & $29(10.4)$ & & $4(1.4)$ & & $1(0.4)$ & & $1(0.4)$ & & \\
\hline \multicolumn{15}{|l|}{$\begin{array}{l}\text { Lista (2006, } \\
\text { 2007) }\end{array}$} \\
\hline $\begin{array}{l}\text { Turdus ili- } \\
\text { acus }\end{array}$ & & 2 & & & & & & & & & & & & \\
\hline $\begin{array}{l}\text { Turdus } \\
\text { merula }\end{array}$ & 8 & 111 & & $8(7.2)$ & & $7(6.3)$ & & $1(0.9)$ & & & & & & \\
\hline $\begin{array}{l}\text { Turdus } \\
\text { pilaris }\end{array}$ & 1 & 18 & & $3(16.7)$ & & $1(5.6)$ & & & & & & & & $2(11.1)$ \\
\hline
\end{tabular}


Table 1. (continued)

\begin{tabular}{|c|c|c|c|c|c|c|c|c|c|c|c|c|c|c|}
\hline \multirow{3}{*}{ Bird species } & \multirow{2}{*}{\multicolumn{2}{|c|}{$\begin{array}{c}\text { No of tested } \\
\text { ticks }\end{array}$}} & \multirow{2}{*}{\multicolumn{2}{|c|}{$\begin{array}{l}\mathrm{n}(\%) \text { of } B b s \mathrm{l} \\
\text { infected ticks }\end{array}$}} & \multicolumn{10}{|c|}{ B. burgdorferi s.l. genospecies, $n(\%)$ of $B b s$ infected ticks } \\
\hline & & & & & \multicolumn{2}{|c|}{$B g$} & \multicolumn{2}{|c|}{$B a$} & \multicolumn{2}{|c|}{$B s s / B g$} & \multicolumn{2}{|c|}{$B a / B g$} & \multicolumn{2}{|c|}{$B v$} \\
\hline & $\mathrm{L}$ & $\mathbf{N}$ & $\mathbf{L}$ & $\mathrm{N}$ & $\mathrm{L}$ & $\mathrm{N}$ & $\mathrm{L}$ & $\mathrm{N}$ & $\mathbf{L}$ & $\mathbf{N}$ & $\mathbf{L}$ & $\mathbf{N}$ & $\mathbf{L}$ & $\mathbf{N}$ \\
\hline $\begin{array}{l}\text { Lullula } \\
\text { arborea }\end{array}$ & 2 & 2 & & & & & & & & & & & & \\
\hline $\begin{array}{l}\text { Oenanthe } \\
\text { oenanthe }\end{array}$ & & 1 & & 1 & & 1 & & & & & & & & \\
\hline $\begin{array}{l}\text { Saxicola } \\
\text { rubetra }\end{array}$ & & 3 & & & & & & & & & & & & \\
\hline $\begin{array}{l}\text { Prunella } \\
\text { modularis }\end{array}$ & 1 & 18 & & & & & & & & & & & & \\
\hline $\begin{array}{l}\text { Anthus } \\
\text { pratensis }\end{array}$ & & 1 & & & & & & & & & & & & \\
\hline $\begin{array}{c}\text { Phylloscopus } \\
\text { trochilus }\end{array}$ & 1 & 2 & & & & & & & & & & & & \\
\hline $\begin{array}{c}\text { Carduelis } \\
\text { chloris }\end{array}$ & 1 & 2 & & & & & & & & & & & & \\
\hline $\begin{array}{l}\text { Sylvia atrica- } \\
\text { pilla }\end{array}$ & & 3 & & & & & & & & & & & & \\
\hline $\begin{array}{c}\text { Sylvia com- } \\
\text { munis }\end{array}$ & 1 & 3 & & & & & & & & & & & & \\
\hline $\begin{array}{l}\text { Sturnus } \\
\text { vulgaris }\end{array}$ & 16 & 15 & & $1(6.7)$ & & & & & & & & & & $1(6.7)$ \\
\hline $\begin{array}{l}\text { Fringilla } \\
\text { coelebs }\end{array}$ & 10 & 4 & & & & & & & & & & & & \\
\hline $\begin{array}{l}\text { Coccotraustes } \\
\text { Coccotraustes }\end{array}$ & & 3 & & & & & & & & & & & & \\
\hline $\begin{array}{l}\text { Luscinia } \\
\text { svecica }\end{array}$ & & 1 & & & & & & & & & & & & \\
\hline Total & 49 & 219 & & $15(6.9)$ & & $11(5.0)$ & & $1(0.5)$ & & & & & & $3(1.4)$ \\
\hline
\end{tabular}

L - larvae, $\mathrm{N}$ - nymphs, Bbsl - B. burgdorferi s.l., Ba - B. afzelii, Bg - B. garinii, Bss - B. burgdorferi s.s., Bv - B. valaisiana

\section{Detection of B. burgdorferi s.l.}

The presence of $B$. burgdorferi s.l. DNA was tested by direct PCR amplification of the ospA gene, localized on lp-54 plasmid in B. burgdorferi s.l. genome. We used primers SL-F and SL-R designed by Demaerschalck et al. (1995) for amplifying $307 \mathrm{bp}$ fragment of ospA gene. Reaction volume of $25 \mu \mathrm{l}$ contained $12.5 \mu \mathrm{l}$ 2x PCR Master Mix (Thermo Fisher Scientific, Lithuania), 20 pmol of each primer (SL-F and SL-R) (Roth, Germany), $6 \mu$ l double-distilled water, and $2.5 \mu \mathrm{l}$ of the processed tick sample. In each PCR run positive (DNA of Borrelia positive ticks) and negative (double distilled water) controls were used. PCR conditions were the following: $95{ }^{\circ} \mathrm{C}$ for $2 \mathrm{~min}$, followed by 40 cycles of $94^{\circ} \mathrm{C}$ for $20 \mathrm{sec} ; 62^{\circ} \mathrm{C}$ for $20 \mathrm{sec}$; and $72{ }^{\circ} \mathrm{C}$ for $30 \mathrm{sec}$. The final extending was at $72{ }^{\circ} \mathrm{C}$ for $2 \mathrm{~min}$. PCR amplification products were separated on $1.5 \%$ agarose gel and visualized by UV transillumination (EASY Win32, Herolab, Germany). The obtained specific products of $307 \mathrm{bp}$ were considered a positive result.

Identification of $B$. burgdorferi s.l. genospecies Multiplex PCR with species-specific primers (Demaerschalck et al., 1995) was performed to differentiate B. burgdorferi s.s, B. garinii, and 
B. afzelii genospecies. Reaction mixture of $30 \mu \mathrm{l}$ contained $15 \mu \mathrm{l}$ Multiplex Master PCR Mix (Qiagen, USA), $20 \mu \mathrm{l}$ of each primers (GI, GII and GIII) (Roth, Germany), and $3 \mu \mathrm{l}$ DNA of the processed tick sample. The cycle consisted of initial denaturation at $95{ }^{\circ} \mathrm{C}-15 \mathrm{~min}$ for HotStart Tag Polymerase activation, denaturation at $95{ }^{\circ} \mathrm{C}$ for $30 \mathrm{~s}$, annealing at $65^{\circ} \mathrm{C}$ for $90 \mathrm{~s}$, and extension at $72{ }^{\circ} \mathrm{C}$ for $60 \mathrm{~s}$. The procedure was repeated 40 times, and the final extension was done at $72{ }^{\circ} \mathrm{C}$ for $2 \mathrm{~min}$. Positive and negative controls were used in each PCR run. PCR amplification products were resolved onto $2.0 \%$ agarose gel and visualized under UV light. The presence of B. valaisiana DNA in tick lysates was tested using species-specific primers (Liebisch et al., 1998) which amplified $549 \mathrm{bp}$ fragment of $16 \mathrm{~S}$ rRNA gene.

\section{DNA sequencing and nucleotide sequences accession numbers}

Nucleotide sequences of Borrelia DNA were confirmed by direct sequencing of amplified B. garinii, B. valasiana, and B. afzelii PCR products. DNA fragments were purified with Nucleospin extract II Kit (Macherey-Nagel, $\mathrm{GmbH} \& \mathrm{Co}$ ). For DNA sequencing reaction, BigDye Terminator v1.1 Cycle Sequencing Kit (Applied Biosystems) was used according to manufacturer recommendations. Sequencing was performed using ABI Prism 310xl Genetic Analyzer (Applied Biosystems Foster City, CA, USA). The obtained sequences were edited and aligned with Borrelia gene sequences registered in GenBank database using the Mega 5.05 software. Partial sequences of the $\operatorname{ssp} A$ gene and 16S rRNA gene were submitted to the GenBank under the following accession numbers: HM623279-HM623295.

In order to investigate the heterogeneity of B. garinii strains found in ticks fed on the birds and rodents, sequences of $345 \mathrm{bp}$ fragment of ospA gene were analyzed and compared with sequences of previously characterized strains submitted in the Gene Bank.

\section{RESULTS}

In both sampling sites a total of 608 feeding (semi-engorged to almost fully engorged) immature ticks (109 larvae and 499 nymphs) were collected from 157 infested birds representing 26 species (Table 1). All ticks belonged to $I$. ricinus species.

Twenty one out of 157 infested (13\%) birds carried B. burgdorferi s.l. infected I. ricinus ticks. The distribution of ticks infected with $B$. burgdorferi s.l. among different bird species are shown in Table 1. B. burgdorferi s.l. DNA was detected in $19.7 \%$ of the tick samples. In total, $6.4 \%(70 / 109)$ of larvae and $10 \%$ (50/499) of nymphs were infected with B. burgdorferi s.l. (Table 1). The observed difference in prevalence of infection was not statistically significant $\left(\chi^{2}=1.36 ; d=1 ; p=0.2430\right)$. The vast majority of infected ticks were found on blackbird T. merula (Table 1). In Jomfruland, 7 out of 33 T. merula (21.2\%) and in Lista, 7 out of 32(21.9\%) carried B. burgdorferi s.l. infected ticks. B. burgdorferi s.l. infected larvae were found only on T. merula species. Borrelia infection was significantly more frequent in ticks collected from birds in Jomfruland $(12.4 \% ; 42 / 340)$ than from those in Lista $(5.6 \% ; 15 / 268)\left(\chi^{2}=8.05 ; d=1 ; p=0.0046\right)$. No Borrelia infected larvae were found in Lista, but in Jomfruland $11.7 \%$ (7/60) of larvae were infected. The prevalence of Borrelia in nymphs collected from birds in Jomfruland was significantly higher compared with those in Lista $\left(12.5 \%\right.$ versus $6.9 \% ; \chi^{2}=4.35 ; d=1$; $p=0.037)$.

Sequence analysis of 15 PCR products confirmed B. garinii (HM623279-HM623290), B. valaisiana (HM623291, HM623292), and B. afzelii (HM623295) species.

The most frequent genospecies was B. garinii (85.5\%), followed by B. afzelii (9.0\%) and B. valaisiana $(5.5 \%)$. B. valaisiana was detected only in bird feeding ticks from Lista (Table 1). Mixed infections with two genospe- 
cies (B. garinii/B. afzelii and B. garinii/B. burgdorgferi s.s.) were detected in two nymphs found in Jomfruland on T. merula.

We identified and compared B. garinii strains obtained in ticks feeding on the avian hosts. Among the 12 ospA sequences obtained from ticks that had fed on birds, five different genotypes were identified (Table 2). The sequences had one or two nucleotide differences at four positions and one deletion. Nine of obtained B. garinii sequences were identical to ospA sequences of OspA serotype 6 type previously characterized and submitted in the GenBank (the ospA sequence of reference strain N34 Y108794, G25 Z290806), whereas four genotypes were unique and have so far not been described (Table 2).

\section{DISCUSSION}

In Norway, several studies have been done to analyze migrating bird infestation with ticks and to assess the role of different bird species in transporting of Borrelia infected ticks (Mehl et al., 1984; Paulauskas et al., 2009; Hasle et al., 2009; 2011; Kielland et al., 2010).

Mehl et al. (1984) showed that in Norway among migratory passerines birds, the most infested birds with Ixodes ricinus ticks were Turdus spp., Erithacus rubecula, Phoenicurus phoenicurus, Prunella modularis, Anthus trivalis, and Luscinia svecica. Hasle et al. (2009), who carried out the study in 2003-2005 from 4 bird observatories along the southern Norwegian coast, found the highest prevalence of tick infestation in thrushes and dunnock (Prunella modularis). Our study conducted during 2006-2007 showed that the most infested bird species found in Jonfruland was T. merula, and in Lista - starling (Sturnus vulgaris) (Paulauskas et al., 2009). According to Kielland et al. (2010), tree pipit (Anthus trivalis), chaffinch (Fringilla coelebs), and whitethroat (Sylvia communis) were found

Table 2. B. garinii genotypes observed among the ospA gene sequences ( $345 \mathrm{bp}$ ) in ticks from birds and rodents

\begin{tabular}{|c|c|c|c|c|c|c|}
\hline \multirow{4}{*}{ Source of $B$. garinii } & \multirow{4}{*}{$\begin{array}{c}\text { GenBank } \\
\text { accession number }\end{array}$} & \multicolumn{5}{|c|}{ Variable sites } \\
\hline & & & & & & 2 \\
\hline & & 7 & 8 & 9 & 9 & 6 \\
\hline & & 6 & 9 & 1 & 3 & 6 \\
\hline Ixodes ricinus from Turdus merula & HM623280 & $\mathrm{T}$ & A & $\mathrm{T}$ & A & G \\
\hline Ixodes ricinus from Turdus merula & HM623281 & . & . & . & . & . \\
\hline Ixodes ricinus from Turdus merula & HM623282 & $\cdot$ & . & . & . & . \\
\hline Ixodes ricinus from Turdus merula & HM623283 & . & . & . & . & . \\
\hline Ixodes ricinus from Turdus merula & HM623284 & . & - & . & . & . \\
\hline Ixodes ricinus from Turdus merula & HM623285 & G & . & $\mathrm{C}$ & $\cdot$ & . \\
\hline Ixodes ricinus from Turdus merula & HM623286 & . & . & . & . & . \\
\hline Ixodes ricinus from Turdus merula & HM623287 & $\cdot$ & . & . & . & . \\
\hline Ixodes ricinus. from Turdus merula & HM623288 & . & . & . & . & . \\
\hline Ixodes ricinus. from Sturnus vulgaris & HM623289 & . & . & . & . & . \\
\hline Ixodes ricinus. from Oenanthe oenanthe & HM623290 & . & . & . & $\cdot$ & $\mathrm{C}$ \\
\hline Ixodes ricinus from Carduelis cannabina & HM623279 & . & . & . & $\mathrm{C}$ & . \\
\hline Ixodes ricinus from Apodemus flavicollis & HM119231 & . & . & . & $\cdot$ & . \\
\hline N34 Y108794 & & . & . & . &. & . \\
\hline G25 Z290806 & & . & . & . & . & . \\
\hline
\end{tabular}

\footnotetext{
“.” indicates the same base; “-” indicates the base deletion
} 
the most commonly infested birds in Lista in 2008.

In the present study the highest infection rate was detected in ticks collected from T. merula in Jomfruland where birds of this species harbored $82 \%$ of B. burgdorferi s.l. infected ticks (Table 1). All infected larvae were carried by T. merula and harbored B. garinii genospecies. Since transovarial transmission is rare, we suggest that the larval ticks most probably have been infected by feeding on the blackbirds.

The dominance of $B$. garinii among ticks collected from birds in this study is in accordance with other studies in Norway and elsewhere (Kielland et al., 2010; Hasle et al., 2011; Hannicová et al., 2003; Taragel’ová et al., 2008; Kurtenbach et al., 2002b). Hasle et al. (2011) found that B. garinii was the dominant species in feeding ticks on birds at Jomfruland, while B. valaisiana and $B$. afzelii were confirmed with a much lower prevalence. However, B.valaisiana dominated in nymphs in Lista, while B. garinii was detected with two-times lower prevalence (Hasle et al., 2011). Kielland et al. (2010) reported that B. garinii was a more frequently found genospecies in bird feeding ticks during autumn migration in Lista.

In order to compare Borrelia genospecies in ticks engorged on migratory birds with genospecies occurred at the investigated localities, we included in analysis the data on prevalence of Borrelia genospecies in questing ticks in Jomfruland and Lista (Table 3; Rosef et al., 2009). However, we did not detect B. garinii species in questing ticks at these locations (Table 3). It is possible that ticks harbored B. garinii were transported by migrating birds from wintering localities. Another possibility is that birds as reservoirs of $B$. garinii genospecies could be an infection source for local ticks. However, if captured birds were the members of the local population, they have spread B. garini infected ticks to the vegetation.

In Lista, questing ticks were collected only in 2007 , and $2.3 \%$ of them were found infected with $B$. afzelii. In Jomfruland, ticks from vegetation were collected at the same time as ticks from birds during 2006 and 2007, and one year later (2008) in the same period. Overall, $5.3 \%$ of questing ticks from Jomfruland were infected, and identified species were B. afzelii, B. burgdorferi s.s. and co-infection of B. afzelii and B. burgdorferi s.s (Table 3).

According to our previous studies, in Jomfruland B. afzelii genospecies was detected in yellow-necked mice Apodemus flavicollis (Paulauskas et al., 2008) and in I. ricinus ticks feeding on yellow-necked mice (Radzijevskaja et al., 2013). The case of co-infection of B. afzelii and B. garinii in a nymph from A. flavicollis was also detected (Radzijevskaja et al., 2013). B. garinii strain detected in ticks that fed on a rodent was identical to that obtained in most of analyzed ticks from birds, and represented OspA serotype 6 strains.

B. afzelii dominated in questing ticks (Table 3), rodents and ticks from rodents in investigated areas, and probably was eliminated in the ticks feeding on birds (Kurtenbach et al., 2002a). B. afzelii infected nymphs obtained on migratory birds in this study could be of local origin.

Table 3. Prevalence of B. burgdorferi s.l. genospecies in questing I. ricinus ticks in Lista and Jomfruland

\begin{tabular}{c|c|c|c|c|c|c|c|c|c|c}
\hline Location & $\begin{array}{c}\text { Female, N } \\
\text { (n) }\end{array}$ & $\begin{array}{c}\text { Male, N } \\
(\mathbf{n})\end{array}$ & Nymph & $\begin{array}{c}\text { Total N } \\
(\mathbf{n})\end{array}$ & $\begin{array}{c}\text { Bbsl } \\
(\%)\end{array}$ & $\boldsymbol{B a}(\mathbf{\%})$ & $\boldsymbol{B g}(\mathbf{\%})$ & $\boldsymbol{B s s}(\mathbf{\%})$ & $\boldsymbol{B} \boldsymbol{v}$ & $\begin{array}{c}\boldsymbol{B a} / \mathbf{B s s} \\
(\%)\end{array}$ \\
\hline Lista (2007) & $43(3)$ & $32(0)$ & $54(0)$ & $129(3)$ & $2.3 \%$ & $3(2.3)$ & - & - & - & - \\
\hline Jomfruland $^{\mathrm{a}}$ & $67(6)$ & $58(2)$ & $118(5)$ & $243(13)$ & $5.4 \%$ & $7(2.9)$ & - & $5(2.1)$ & - & $1(0.4)$
\end{tabular}

$(2006 / 7 / 8)$

$\mathrm{N}$ - number of tested ticks, $\mathrm{n}$ - number of infected ticks, Bbsl - B. burgdorferi s.l., Ba - B. afzelii, Bg - B. garinii, Bss - B. burgdorferi s.s., Bv - B. valaisiana

${ }^{a}$ Rosef et al., 2009 
The occurrence of B. burgdorferi s.l. genospecies in ticks collected from blackbirds could be related to migration routes. According to the investigation of migration behavior of T. merula in Western Europe, the breeding range of the blackbird covers the entire region except for the extreme north of Fennoscandia. Britain and Ireland are important host areas for Fennoscandian blackbirds (Main, 2002). Thousands of blackbirds arrive in Norway from Great Britain at the end of March and early April. Studies conducted in the British Islands (Kurtenbach et al., 1998; Kurtenbach et al., 2001; Kurtenbach et al., 2002b) showed that the most prevalent genospecies in $I$. ricinus ticks was $B$. garinii, followed by B. valaisiana and $B$. burgdorferi s.s. with low prevalence (below 1\%). B. garinii seems to be adapted to birds (Kurtenbach et al., 2002a) and that may influence infection of birds with $B$. garinii and consequently $B$. garinii infection in feeding ticks found on T. merula in the southern coast of Norway.

\section{CONCLUSIONS}

Most of the infected ticks were found on blackbird T. merula. The most frequent genospecies was B. garinii (85.5\%), followed by B. afzelii (9.0\%) and B. valaisiana (5.5\%). The Turdus species have a potential of hosting and spreading $I$. ricinus ticks and Borrelia. We did not detect $B$. garinii species in questing ticks at the investigated locations. However, B. afzelii genospecies dominated in questing ticks, in rodents and ticks from rodents, and probably was eliminated in the ticks feeding on birds.

\section{ACKNOWLEDGEMENTS}

This study was supported by the Telemark University College and Lithuanian State Science and Studies Foundation.

Received 7 April 2015

Accepted 27 June 2016

\section{References}

1. Acheson CW. The status of the Blackbird (Turdus merula) at the Copeland Bird Observatory, Co Down. CBO Annual Report. 1975. doi: http://www.copelandbirdobservatory.org.uk/ bbird.htm.

2. Comstedt P, Bergström S, Olsen B, Garpmo U, et al. Migratory passerine birds as reservoirs of Lyme borreliosis in Europe. Em Infect Dis. 2006; 12: 1087-95.

3. Demaerschalck I, BenMessaoud A, De Kesel M, Hoyois B, et al. Simultaneous presence of different Borrelia burgdorferi genospecies in biological fluids of Lyme disease patients. J Clin Microbiol. 1995; 33: 602-8.

4. Filippova N. Ixodovye kleshi podsem. Ixodinae (Ixodid ticks of the subfamily Ixodinae). Fauna SSSR. Leningrad: Nauka; 1977.

5. Hanincová K, Taragelova V, Koci J, Schafer SM, et al. Association of Borrelia garinii and B. valaisiana with songbirds in Slovakia. Appl Environ Microbiol. 2003; 69: 2825-30.

6. Hasle G, Bjune G, Edvardsen E, Jacobsen C, et al. Transport of ticks by migratory passerine birds to Norway. J Parasitol. 2009; 95: 1342-151.

7. Hasle G, Bjune G, Midthjell L, Røed KH, et al. Transport of Ixodes ricinus infected with Borrelia species to Norway by northward-migrating passerine birds. Ticks and Tick-borne Diseases. $2011 ; 2: 37-43$.

8. Hillyard R. Ticks of North-West Europe. Synopsis of the British fauna (new series). Barnes RSK, Crothers JH, editors. The Natural Historical Museum, London; 1996.

9. Kipp S, Goedecke A, Dorn W, Wilske B et al. Role of birds in Thuringia, Germany, in the natural cycle of Borrelia burgdorferi sensu lato, the Lyme disease spirochaete. Int J Med Microbiol. 2006; 40: 125-8. 
10. Kielland V, Stuen S, Skarpaas T, Slettan A. Borrelia burgdorferi sensu lato in Ixodes ricinus ticks collected from migratory birds in Southern Norway. Acta Vet Scand. 2010; 52: 59. doi:10.1186/1751-0147-52-59.

11. Kurtenbach K, De Michelis S, Etti S, Schäfer SM, et al. Host association of Borrelia burgdorferi sensu lato - the key role of host complement. Trends Microbiol. 2002a; 10: 74-9.

12. Kurtenbach K, S De Michelis, Sewell HS, Etti S, et al. Distinct combinations of Borrelia burgdorferi sensu lato genospecies found in individual questing ticks from Europe. Appl Environ Microbiol. 2001; 67: 4926-9.

13. Kurtenbach K, Peacey M, Rijpkema S, Hoodless $\mathrm{A}$, et al. Differential transmission of the genospecies of Borrelia burgdorferi sensu lato by game birds and small rodents in England. Appl Environ Microbiol. 1998; 64: 1169-74.

14. Kurtenbach K, Schäfer SM, Sewell HS, Peacey $M$, et al. Differential survival of Lyme borreliosis spirochetes in ticks that feed on birds. Infect Immun. 2002b; 70: 5893-5.

15. Liebisch G, Sohns B, Bautsch W. Detection and typing of Borrelia burgdorferi sensu lato in Ixodes ricinus ticks attached to human skin by PCR. J Clin Microbiol. 1998; 36: 3355-8.

16. Main IG. Seasonal movements of Fennoscandian Blackbirds Turdus merula. Ringing Migr. 2002; 21: 65-74.

17. Mehl R, Lid G, Michaelsen J. Ticks (Acari, Ixodides) on migratory birds in Norway. Fauna Norvegica Serie B Norw J Entomol. 1984; 31: 46-58.

18. Olsen B, Jaenson T, Bergström S. Prevalence of Borrelia burgdorferi sensu lato-infected ticks on migrating birds. Appl Environ Microbiol. 1995; 61: 3082-7.
19. Paulauskas A, Rosef O, Galdikaite E, Radzijevskaja J. Infestation with Ixodes ricinus ticks on migrating passerine birds in Lithuania and Norway. Acta Biol Univ Daugavp. 2009; 9: 1-6.

20. Paulauskas A, Ambrasiene D, Radzijevskaja J, Rosef $\mathrm{O}$, et al. Diversity in prevalence and genospecies of Borrelia burgdorferi sensu lato in Ixodes ricinus ticks and rodents in Lithuania and Norway. Int J Med Microbiol. 2008; 298(S1): 180-7.

21. Radzijevskaja J, Paulauskas A, Rosef O, Petkevičius $S$, et al. The propensity of voles and mice to transmit Borrelia burgdorferi sensu lato infection to feeding ticks. Vet Parasitol. 2013; 197: 318-25. doi: http://dx.doi. org/10.1016/j.vetpar.2013.06.008.

22. Rijpkema S, Golubic D, Molkenboer M, Verbeek-De Kruif N, et al. Identification of four genomic groups of $B$. burgdorferi sensu lato in $I$. ricinus ticks collected in a Lyme borreliosis endemic region of Northern Croatia. Exp Appl Acarol. 1996; 20: 23-30.

23. Rosef O, Paulauskas A, Radzijevskaja J. Prevalence of Borrelia burgdorferi sensu lato and Anaplasma phagocytophilum in questing $I x$ odes ricinus ticks in relation to the density of wild cervids. Acta Vet Scand. 2009; 51: 47-54.

24. Ruzic-Sabljic E, Zore A, Strle F. Characterization of Borrelia burgdorferi sensu lato isolates by pulse-field gel electrophoresis after MluI restriction of genomic DNA. Res Microbiol. 2008; 159: 441-8.

25. Stanek G, Reiter M. The expanding Lyme Borrelia complex - Clinical significance of genomic species. Clin Microbiol Infect. 2011; 17: 487-93.

26. Taragel’ová V, Koči J, Hannicová K, Kurtenbach $K$, et al. Blackbirds and song trushes constitute a key reservoir of Borrelia garinii, the causative agent of borreliosis in central Europe. Appl Environ Microbiol. 2008; 74: 1289-93. 
Jana Radzijevskaja, Olav Rosef, Vesta Matulaitytè, Algimantas Paulauskas

\section{IXODES RICINUS ERKIŲ, MINTANČIŲ ANT ŽVIRBLINIŲ PAUKŠČIŲ, BORRELIA BURG- DORFERI SENSU LATO GENOTIPAI PIETŲ NORVEGIJOJE}

\section{Santrauka}

Paukščiai yra svarbūs erkių pernešamų patogenų platintojai. Pagrindinis šio tyrimo tikslas buvo ištirti Bortrelia burgdorferi sensu lato genotipų paplitimą tarp Ixodes ricinus erkių, surinktų nuo žvirblinių paukščių iš dviejų ornitologinių stočių (Jomfruland ir Lista) Pietų Norvegijoje. Tirtose vietose nuo 157 užkrèstų paukščių, atstovaujančių 26 rūšims, surinkta 608 (109 lervos ir 499 nimfos) nesubrendusios erkès. Siekiant nustatyti $B$. burgdorferi s. 1., erkèse gausinamas specifinis ospA genas, kuris aptinka- mas lp-54 genominèje plazmidèje. Iš 157 užsikrètusių paukščiu 21 pernešè I. ricinus erkes, užkrèstas B. burgdorferi s. 1. B. burgdorferi s. 1. patogenų aptikta 19,7 \% mėginių. Iš viso 6,4 \% lervų (7/109) ir $10 \%$ nimfų (50/499) mėginių buvo teigiami. Daugiausiai užsikrètusių erkių nurinkta nuo juodojo strazdo (Turdus merula). Dažniausias genotipas buvo B. garinii (85,5 \%), mažiau paplitę - B. afzelii (9 \%) ir B. valaisiana (5,5\%). Identifikuoti penki skirtingi B. garinii tipai. Rezultatai rodo, kad juodasis strazdas gali dalyvauti $B$. garinii ir B. valaisiana bakterijų cirkuliacijoje ir paplitime. Iš tirtų vietų surinktose erkèse B. garinii neidentifikuota. Tarp erkių, graužikų ir erkių, surinktų nuo graužikų, dominavo B. afzelii genotipas.

Raktažodžiai: žvirbliniai paukščiai, Ixodus ricinus erkès, Borrelia burgdorferi s. 1. genotipai 